\title{
Possibility of Producing Hydrogen from Water by Electrolysis as a Renewable Source of Energy
}

\author{
Mohamed Hany*, Adel H. Bahnasawy** and Enas Haza'a*** \\ * Graduate Student of Agric. Eng. Dep., Fac. of Agric., Damanhour Univ., Egypt \\ ** Professor of Agric. Eng., Fac. of Agric., Benha Univ., Egypt \\ *** Lecturer of Agric. Eng., Fac. of Agric., Damanhour Univ., Egypt \\ Corresponding author: alsayed.khater@fagr.bu.edu.eg
}

\begin{abstract}
The main aim of this study is to investigate the possibility of producing hydrogen gas from water by electrolysis as renewable source of energy. To achieve that, a simplified unit of water electrolysis was developed and evaluated. Five types of water (4000 ppm, 6000 ppm, 8000 ppm, alkaline water (10\% wt KOH) and seawater) were used, three distance between electrodes namely 6, 4 and $2 \mathrm{~mm}$ were also investigated. Hydrogen yield, energy requirements, and energy output were studied. Unit efficiency and cost of hydrogen production was also determined. The obtained results indicate that the energy requirements for hydrogen production increases with decreasing distance between electrodes and increasing operating time. The hydrogen yield increases with decreasing distance between electrodes and increases with increasing operating time, where it ranged from 1.977 to $36.997 \mathrm{~L} \mathrm{~h}^{-1}$ for all treatments. The energy output increases with decreasing distance between electrodes and increases with increasing operating time which ranged from 0.007 to $0.180 \mathrm{kWh}$ for all treatments. The hydrogen production unit efficiency ranged from 25.36 to $80.32 \%$ for all treatments. The total costs of hydrogen production unit ranged from 0.040 to $0.069 \mathrm{LE} \mathrm{kg}^{-1}$ of hydrogen.
\end{abstract}

Keywords: Hydrogen - Electrolysis - Energy - Efficiency - Cost

\section{Introduction}

Global energy consumption is expected to increase continuously in the next decades, driven by rising standards of living and growing population worldwide. The increased need for more energy will require growth in energy generation capacity and more secure and diversified energy sources (USDOE, 2009).

The need for a sustainable energy supply is obvious due to depletion of fossil energy resources, environmental pollution, climate change and increasing dependency on fossil fuels exporting countries. Fossil fuel combustion or reformation causes adverse environmental impacts, which motivate researchers to look for environmentally sustainable alternative fuels. Those alternative fuels are required to fulfill criteria such as no or less release of carbon dioxide $\left(\mathrm{CO}_{2}\right)$, suitability for both mobile and stationary applications and affordable price range (Romagnoli et al., 2011).

Hydrogen, a kind of clean energy with the highest specific energy density, is considered as the best alternative to fossil fuel in order to ensure global stability and sustainability. However, the majority of hydrogen is still produced from fossil fuels. Therefore, technologies for hydrogen generation from renewable resources must be developed and applied. Hydrogen produced by water electrolysis has many advantages such as high purity, simple and green process. Although hydrogen can be also produced by photocatalytic water splitting, this technology is still in experimental stage due to low efficiency and high cost (Osterloh, 2008).

Hydrogen has several advantages associated with its use: can be produced using renewable energy resources; has high yields in fuel cells; undergoes clean combustion without emissions of $\mathrm{CO}_{2}$ and oxides of nitrogen and sulfur $\left(\mathrm{NO}_{\mathrm{x}}, \mathrm{SO}_{\mathrm{x}}\right)$; and makes the indirect storage of the intermittent renewable energy resources feasible (Balat, 2008 and Muradov and Veziroglu, 2008).

Like electricity, hydrogen is an energy carrier and not a primary energy source. Hydrogen is so far mainly used for non-energetic purposes in different industrial applications (>95\% of global hydrogen production). Ammonia production is the largest consumer sector (about 62.4\%). Its energetic use is very small (Spath and Mann, 2001). Some authors state the global hydrogen production amount of about 500 billion $\mathrm{Nm}^{3} / \mathrm{yr}$ (Saur, 2008).

Although there might be a mass production of hydrogen using renewable energy in the long term, fossil fuels are the major sources for its production today (Dufour et al., 2011).

Globally, the hydrogen production sources were about $48 \%$ from natural gas, $30 \%$ from fossil oil, $18 \%$ from coal and the rest with electricity via water electrolysis (IEA, 2005). This share may not change drastically in a near future; though coal, the most abundant primary energy source in many countries worldwide, might have a higher share than natural gas. Electrolytic hydrogen production could also be in 
focus, if the hydrogen is produced using renewable energy generated electricity.

In recent years, there has been an increasing interest in using water electrolysis in hydrogen production as an energy source due to rising energy prices caused by fossil fuel shortages and growing energy demands. Moreover, in contrast to fossil fuels, hydrogen is considered to be a renewable source. Thus, hydrogen production methods are seen as one of the most promising alternatives to conventional fuels. Hydrogen can be produced through a wide range of processes, e.g., combustion, pyrolysis, gasification and fermentation. At present, the best way to produce hydrogen is by electrolysis using electricity produced from sustainable energy sources such as solar, wind, and even nuclear, etc. At present, only about $5 \%$ of hydrogen in the world is produced by water electrolysis (Smolinka et al., 2011).

Several technologies are available in the market for commercial hydrogen production. The first commercial technology to produce pure hydrogen, dating back to the late 1920 s, was water electrolysis. In the $1960 \mathrm{~s}$, industrial hydrogen production shifted toward fossil based feedstock, which is the main source for hydrogen production until today (IEA, 2006). Currently, only about $4 \%$ of global hydrogen production is based on electrolysis (Padro and Putsche, 1999, Häussinger et al., 2007). Other studies already give a detailed technical overview on different hydrogen production techniques, e.g. (Holladay et al., 2009). Various hydrogen production technologies by outlining economics, environmental impacts, applications and hydrogen energy status around the world are also studied in other literatures, e.g. (Momirlan and Veziroglu, 2002). Ursua et al. (2012) have thoroughly reviewed the state of the art of different electrolytic hydrogen production technologies. Energy saving possibilities in electrolytic technologies are discussed by Stojic et al. (2003).

The energy demand of an alkaline electrolyzer is dependent on the characteristics of the electrodes and operational conditions. Atmospheric electrolyzers have a specific energy demand of about 4.1$4.5 \mathrm{kWh} / \mathrm{Nm}^{3} \mathrm{H}_{2}$ and pressurized electrolyzers have a demand of about $4.5-5 \mathrm{kWh} / \mathrm{Nm}^{3} \mathrm{H}_{2}$. Additionally, the atmospheric electrolyzers need energy for the compression of produced hydrogen resulting in a total plant energy demand of about 4.5$7 \mathrm{kWh} / \mathrm{Nm}^{3} \mathrm{H}_{2}$ (Smolinka et al., 2011). The atmospheric electrolyzers have an efficiency up to $85 \%$ (HHV) and the high pressure ones have up to $78 \%$ (HHV) (Smolinka et al., 2011). The life time of an alkaline electrolyzer is reported to be up to 30 years, though a general overhaul is necessary every 715 years to replace/reactivate the electrodes and to replace the diaphragms (Pehnt, 2001, Wenske, 2008, Smolinka et al., 2011).

The main aim of this work is to develop a simplified unit of hydrogen production from water by electrolysis. Test and evaluate the unit by studying some factors affecting the performance of this unit. Water with different concentrations of salt and the distance between electrode were the most important factors chosen. Energy consumed and energy produced were determined. Unit efficiency and economical evaluation was also studied.

\section{Materials and methods}

The experiment was carried out at Agricultural and Bio-Systems Engineering Department, Faculty of Agriculture Moshtohor, Benha University, Egypt. During the period of July to September, 2019 season to study the possibility of operating a small engine by the hydrogen gas produced from water.

\section{Materials:}

\section{Unit description:}

Figure (1) illustrates the hydrogen production unit description. It consists of an external cover, a group of cells (stainless steels) and between which there is an interval of Gasket rubber flex, the unit is grouped with nails. There are two openings of the entry and exit of the entry of water and hydrogen gas exit slot. The ingress of water between the positive and negative cells that that run on water separated into two hydrogen atom and oxygen atom. Hydrogen gas comes out of the top slot of the lid of the unity of hydrogen gas production to the highest water tank. Acrylic cover dimension was $20 \times 20 \mathrm{~cm}$ were used to cover and link the hole unit. 


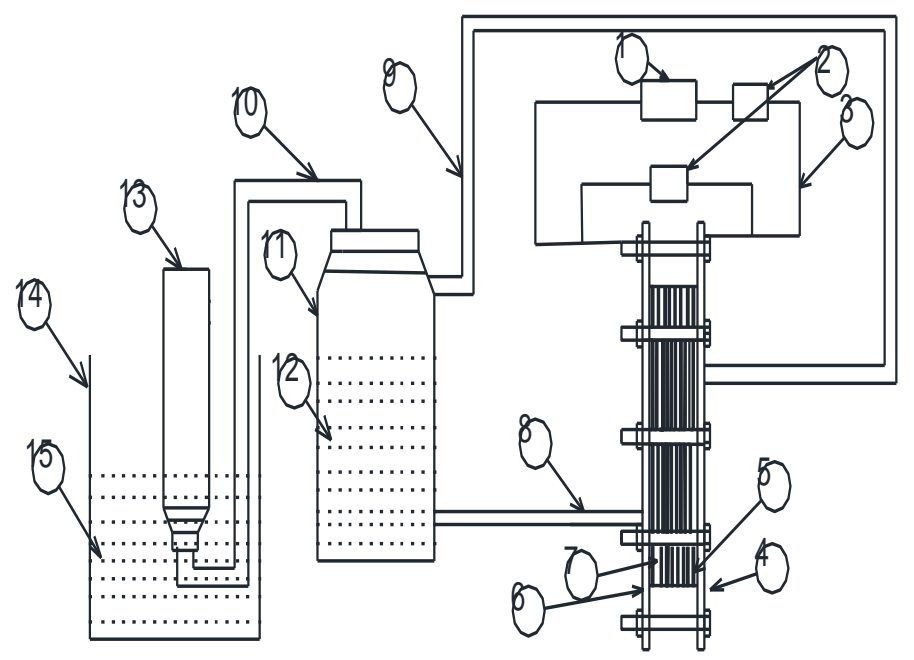

1-DC power supplier

2-Avo meter

3-Power cord (wire)

4-fuel cell

5-stainless steel plate

6-the outer cover of acrylic

7- separator (gasket)

8- plastic hose connecting water
9- plastic hose connecting gas and water 10 - plastic hose connecting gas of hydrogen

11 - water tank

12- water

13 - hydrogen collector

14- open water tank

15- water

Figure (1): The experimental setup.

The system consists of polyethylene water container $5 \mathrm{~L}$ capacity $(16 \mathrm{~cm}$ diameter and $32 \mathrm{~cm}$ height). A circular exit of $1.5 \mathrm{~cm}$ diameter was cut on the $10 \mathrm{~cm}$ upper opening. A hose of $1.25 \mathrm{~cm}$ diameter was connected to the water tank upper opening through a small tube. The volume of water in the reservoir and the connection of a compound diameter of $1.5 \times 1.25 \mathrm{~cm}$ connected to a hose through which the output of the highest gas module connector production of hydrogen gas cells with the remaining water from the analysis. It leaves the tank upper part, up $5 \mathrm{~cm}$ are output gas gathering for an interim period before it passes the drying stage and collected leads to increase the gas pressure on the surface of the water which increases the pressure pushing water into the unit of analysis.

Power was supplied to the unit by using a 12 Volt battary in this system as a source of electricity to operate the hydrogen gas production unit. It used to convert from $\mathrm{AC}$ to $\mathrm{DC}$. The outlet power of power supply is 12 Volts and 10 Amps.

Kutcher flexible Gaskets rectangular in shape were used for its guardian compression ratio. They were used to isolate the positive cells from the negative cells and prevent water leaking user cells as it works on not leaking hydrogen gas output of the unit. Local manufactured gaskets are available in various thicknesses of $2 \mathrm{~mm}, 4 \mathrm{~mm}$, and $6 \mathrm{~mm}$. The gasket has dimensions of $16 \times 14 \mathrm{~cm}$.

Flexible plastic hoses of different diameters (Egyptian made) were used to link between hydrogen gas production and the water tank and between water tank and the copper check valve.

Bolts Nuts and washers from galvanized iron homemade Format 14, $12 \mathrm{~mm}$ and a length of 10, 7.5 $\mathrm{cm}$ which is to connect the hydrogen production unit Bolts Nuts and washers $10 \mathrm{~cm}$ long, $14 \mathrm{~mm}$ diameter is connected to the intensity of the power of the unit through it. The bolts Nuts and washer's length of 7.5 $\mathrm{cm}$, diameter $12 \mathrm{~mm}$ dedicated to connecting the unit with its provisions from the infusion to be the circuit closed during gas production.

\section{Methods: \\ 1. Treatments:}

The treatments include: five water types $(4000$ ppm, 6000 ppm, 8000 ppm, alkaline water (10\% wt $\mathrm{KOH})$ and sea water (36000 ppm) ) and three distance between electrodes were 2,4 and $6 \mathrm{~mm}$. The experimental design was a split plot. 


\section{Measurements:}

The power requirement was estimated by using the clamp meter (Model MY-61; Range: 0 to 1000 Volts and 0 to $200 \mathrm{Amps}$, China) to measure the line current strength (I) and the potential difference value (V).

The total electric power $(\mathrm{P})$ was calculated according to Kurt (1979) by the following equation:

$$
P=I \times V \times \cos \theta
$$

Where:

$\mathrm{P}$ is the electric power, $\mathrm{W}$

I is the line current strength, Amperes.

$\mathrm{V}$ is the potential difference, Voltage.

$\operatorname{Cos} \theta$ is the power factor, equal 0.8 .

Hydrogen produced was collected in a scaled flask and recorded each $10 \mathrm{~min}$.

Electrolyzer efficiency was calculated according the following equation:

$$
\eta=\frac{\mathrm{NH}_{2} \times H H V}{\mathrm{E}} \times 1000
$$

Where:

$\eta$ is the unit efficiency, $\%$.

$\mathrm{NH}_{2}$ is the hydrogen production rate, $\mathrm{m}^{3} \mathrm{~h}^{-1}$.

$\mathrm{HHV}$ is the hydrogen high heating value, $39.40 \mathrm{kWh} \mathrm{m}^{-3}$.

$\mathrm{E}$ is the electric energy inputs, $\mathrm{kW}$.

\subsubsection{Total Costs}

The cost calculation based on the following parameters was also performed:

- Depreciation costs $\left(\mathrm{D}_{\mathrm{c}}\right)$ :

$$
\eta=\frac{\mathrm{P}_{\mathrm{d}}-S_{r}}{\mathrm{~L}_{\mathrm{d}}}
$$

Where:

Dc is the depreciation cost, LE year ${ }^{-1}$

$\mathrm{P}_{\mathrm{d}}$ is the automatic feeder purchase price, 10000 LE.

$\mathrm{Sr}$ is the salvage rate $\left(0.1 \mathrm{P}_{\mathrm{d}}\right) \mathrm{LE}$.

$\mathrm{Ld}$ is the automatic feeder life, 5 year. - Interest costs (In):

$I_{n}=\frac{P_{d}+S_{r}}{2} \times \mathrm{i}_{\mathrm{n}}$

Where:

$\mathrm{I}_{\mathrm{n}}$ is the interest, LE year ${ }^{-1}$.

$\mathrm{i}_{\mathrm{n}}$ is the interest as compounded annually, decimal. $(12 \%)$

Shelter, taxes and insurance costs $(\mathrm{Si})$ :

Shelter, taxes and insurance costs were assumed to be $3 \%$ of the purchase price of the automatic feeder $\left(\mathrm{P}_{\mathrm{m}}\right)$.

Then:
Fixed cost $\left(\mathrm{LE} \mathrm{h}^{-1}\right)=\mathrm{Dc}+\mathrm{In}+0.03 \mathrm{Pm} /$ hour of use per year

- Repair and maintenance costs $\left(\mathrm{R}_{\mathrm{m}}\right)$ :

$R_{m}=100 \%$ deprecation cost / hour of use per year

- Energy costs (E):

$\mathrm{E}=\mathrm{EC} \times \mathrm{EP}$

(7)

Where:

$\mathrm{E}$ is the energy costs, $\mathrm{LE} \mathrm{h}^{-1}$.

EC is the electrical energy consumption, $\mathrm{kWh}$.

$\mathrm{EP}$ is the energy price, $0.57 \mathrm{LE} \mathrm{kW}^{-1}$.

- Labor costs (La):

$\mathrm{La}=$ Salary of one worker $\mathrm{x}$ No. of workers

Where:

$\mathrm{La}$ is the Labor costs, $\mathrm{LE} \mathrm{h}^{-1}$.

Salary of one worker $=10 \mathrm{LE} \mathrm{h}^{-1}$. No. of workers $=1$

Then: (2)

Variable costs $\left(\mathrm{LE} \mathrm{h}^{-1}\right)=\mathrm{R}_{\mathrm{m}}+\mathrm{E}+\mathrm{La}$

Variable costs $\left(\mathrm{LE} \mathrm{h}^{-1}\right)$

Total costs $\left(\mathrm{LE} \mathrm{h}^{-1}\right)=$ Fixed costs $\left(\mathrm{LE} \mathrm{h}^{-1}\right)+$

\section{Results and Discussion}

\section{Energy requirements:}

Figure (2) shows the accumulated required energy of hydrogen production at different water types $(4000$ ppm, 6000 ppm, 8000 ppm, alkaline water $(10 \%$ wt $\mathrm{KOH})$ and sea water) and different distance between electrodes (2, 4 and $6 \mathrm{~mm}$ ) during the experimental per 30$) d$. The results indicate that the accumulated required energy of hydrogen production decreases with increasing distance between cells and increases with increasing operating time. It could be seen that the accumulated required energy of hydrogen production decreased from 0.092 to 0.078 and 0.910 to $0.752 \mathrm{~kW} \mathrm{~h}$, when the distance between electrodes increased from 2 to $6 \mathrm{~mm}$, respectively, for water type of $4000 \mathrm{ppm}$. The results also indicate that the operating time decreases with decrasing the distance betwwen cells. It could be seen that the operating time decreased from $\$ 40$ to $180 \mathrm{~min}$, when the distance between electrodes decrease from 6 to $2 \mathrm{~min}$, respectively.

For water type of $6000 \mathrm{ppm}$, the accumulated required energy of hydrogen production decreased from 0.029 to 0.027 and 0.288 to $0.266 \mathrm{~kW} \mathrm{~h}$, when the distance between electrodes decreased from 6 to 2 $\mathrm{mm}$, respectively after 10 and $160 \mathrm{~min}$ of operating time. The results also indicate that the operating time decreases with decrasing the distance betwwen cells. It could be seen that the operating time decreased from 260 to $160 \mathrm{~min}$, when the distance between electrodes decrease from 6 to $2 \mathrm{~min}$, respectively. 


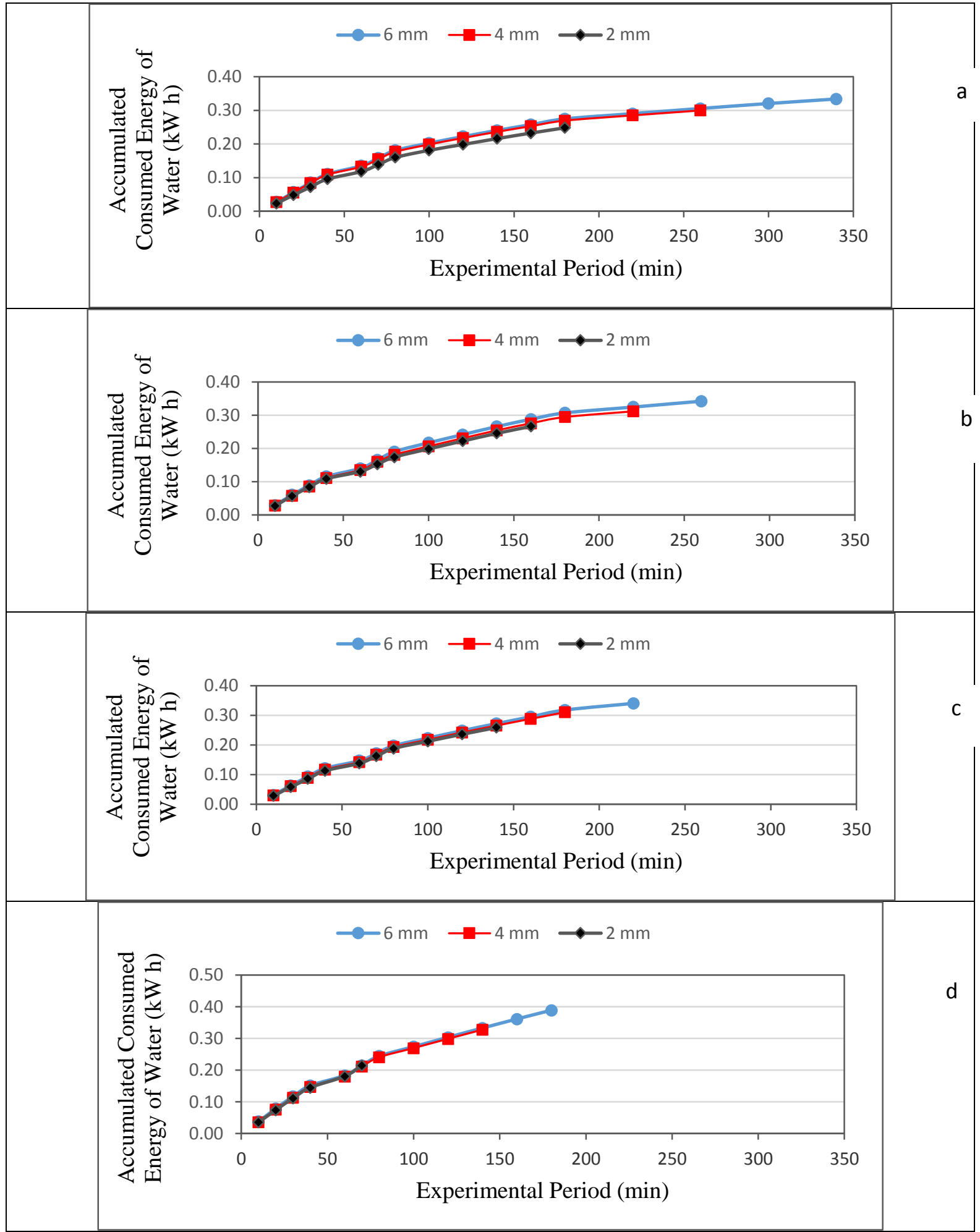




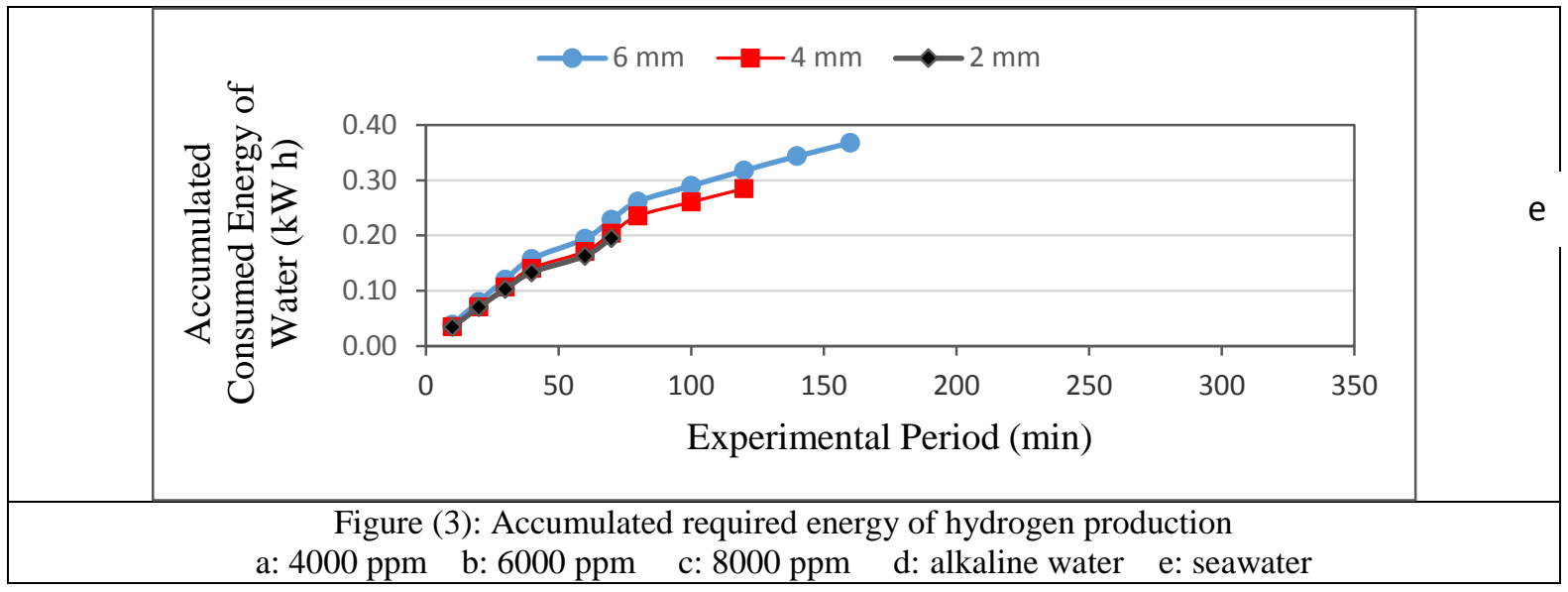

For water type of $8000 \mathrm{ppm}$, the accumulated required energy of hydrogen production decreased from 0.031 to 0.029 and 0.272 to $0.259 \mathrm{~kW} \mathrm{~h}$, when the distance between electrodes decreased from 6 to 2 $\mathrm{mm}$, respectively after 10 and $140 \mathrm{~min}$ of operating time. The results also indicate that the operating time decreases with decrasing the distance betwwen cells. It could be seen that the operating time decreased from 220 to $140 \mathrm{~min}$, when the distance between electrodes decrease from 6 to $2 \mathrm{~min}$, respectively.

For water type of alkaline water $(10 \%$ wt $\mathrm{KOH})$, the accumulated required energy of hydrogen production decreased from 0.038 to 0.036 and 0.215 to $0.214 \mathrm{~kW} \mathrm{~h}$, when the distance between electrodes decreased from 6 to $2 \mathrm{~mm}$, respectively after 10 and $70 \mathrm{~min}$ of operating time. The results also indicate that the operating time decreases with decrasing the distance betwwen electrodes. It could be seen that the operating time decreased from 180 to $70 \mathrm{~min}$, when the distance between electrodes decrease from 6 to 2 min, respectively.

For water type of seawater, the accumulated required energy of hydrogen production decreased from 0.039 to 0.034 and 0.229 to $0.195 \mathrm{~kW} \mathrm{~h}$, when the distance between electrodes decreased from 6 to 2 $\mathrm{mm}$, respectively after 10 and $70 \mathrm{~min}$ of operating time. The results also indicate that the operating time decreases with decrasing the distance betwwen cells. It could be seen that the operating time decreased from 160 to $70 \mathrm{~min}$, when the distance between electrodes decrease from 6 to $2 \mathrm{~min}$, respectively.

The results also indicate that the highest values of accumulated required energy of hydrogen production were $0.334,0.342,0.340,0.389$ and $0.368 \mathrm{~kW} \mathrm{~h}$ for 4000 ppm, 6000 ppm, 8000 ppm, alkaline water (10\% wt $\mathrm{KOH}$ ) and seawater of types of water, respectively at $6 \mathrm{~mm}$ distance between cells. While, the lowest values of accumulated required energy of hydrogen production were $0.248,0.266,0.259,0.214$ and 0.195 $\mathrm{kW}$ h for $4000 \mathrm{ppm}, 6000 \mathrm{ppm}, 8000$ ppm, alkaline water $(10 \%$ wt $\mathrm{KOH})$ and seawater of types of water, respectively at $2 \mathrm{~mm}$ distance between electrodes.

\subsection{Accumulated produced hydrogen of water:}

Figure (4) shows the accumulated produced hydrogen of water at different water types (4000 ppm,
6000 ppm, 8000 ppm, alkaline water (10\% wt KOH) and sea water) and different distance between electrodes $(6,4$ and $2 \mathrm{~mm})$ during the experimental period. The results indicate that the accumulated produced hydrogen of water increases with decreasing distance between electrodes and increases with increasing operating time. It could be seen that the accumulated produced hydrogen of water increased from 1.977 to 3.546 and 21.04 to $34.749 \mathrm{~kg} \mathrm{~h}^{-1}$, when the distance between electrodes decreased from 6 to 2 $\mathrm{mm}$, respectively, for water type of $4000 \mathrm{ppm}$ after 10 and $180 \mathrm{~min}$ of operating time. The results indicate that the operating time decreases with decrasing the distance betwwen electrodes. It could be seen that the operating time decreased from 340 to $180 \mathrm{~min}$, when the distance between electrodes decrease from 6 to 2 $\mathrm{min}$, respectively, for water type of $4000 \mathrm{ppm}$.

The regression between the accumulated produced hydrogen and operating time for different distance between electrodes $(6,4$ and $2 \mathrm{~mm}$ ) for 4000 ppm water type is show the following equation:

For $6 \mathrm{~mm}$

$\mathrm{PE}=1.518 \mathrm{OT}+18.212 \quad \mathrm{R}^{2}=0.97$

For $4 \mathrm{~mm}$

$\mathrm{PE}=0.416 \mathrm{OT}+13.372 \quad \mathrm{R}^{2}=0.92$

For $2 \mathrm{~mm}$

$\mathrm{PE}=0.125 \mathrm{OT}+6.953 \quad \mathrm{R}^{2}=0.90$

Where:$\left(\mathrm{kg} \mathrm{h}^{-1}\right)$

$\mathrm{PE}$ is the accumulated produced hydrogen

OT is the operating time ( $\mathrm{min}$ )

For water type of $6000 \mathrm{ppm}$, the accumulated produced hydrogen of water increased from 2.364 to 4.255 and 18.676 to $34.988 \mathrm{~kg} \mathrm{~h}^{-1}$, when the distance between electrodes decreased from 6 to $2 \mathrm{~mm}$, respectively after 10 and 160 min of operating time. The results also indicate that the operating time decreases with decrasing the distance betwwen electrodes. It could be seen that the operating time decreased from 260 to $160 \mathrm{~min}$, when the distance between electrodes decrease from 6 to $2 \mathrm{~min}$, respectively.

The regression between the accumulated produced hydrogen and operating time for different distance 
between electrodes $(6,4$ and $2 \mathrm{~mm})$ for $6000 \mathrm{ppm}$ water type is show the following equation:

For $6 \mathrm{~mm}$

$$
\begin{array}{rr}
\mathrm{PE}=1.813 \mathrm{OT}+13.259 \\
\mathrm{R}^{2}=0.97
\end{array}
$$

For $4 \mathrm{~mm}$

For $2 \mathrm{~mm}$
$\mathrm{PE}=0.568 \mathrm{OT}+13.098$

$\mathrm{R}^{2}=0.94$

$\mathrm{PE}=0.329 \mathrm{OT}+17.756$

$\mathrm{R}^{2}=0.93$

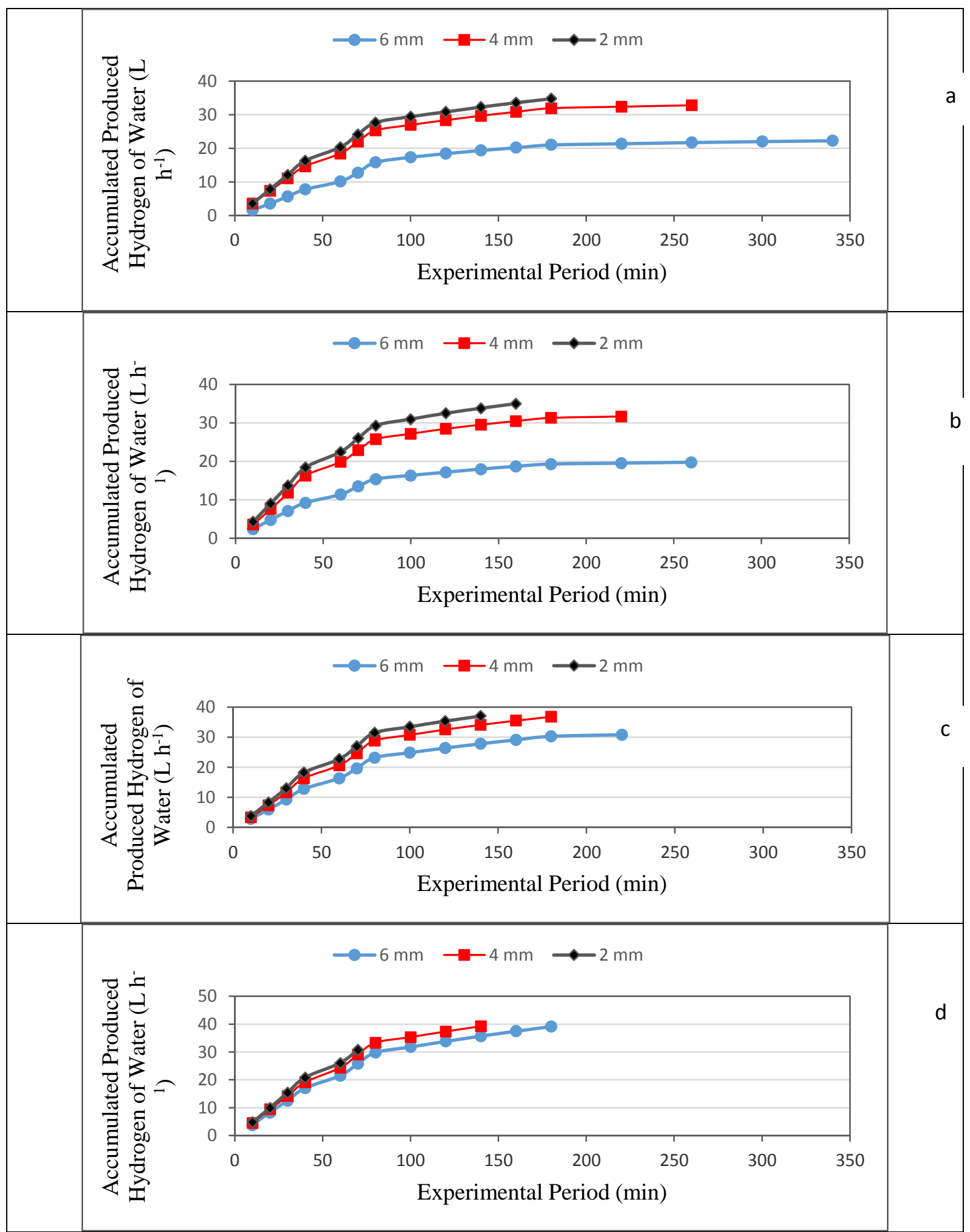




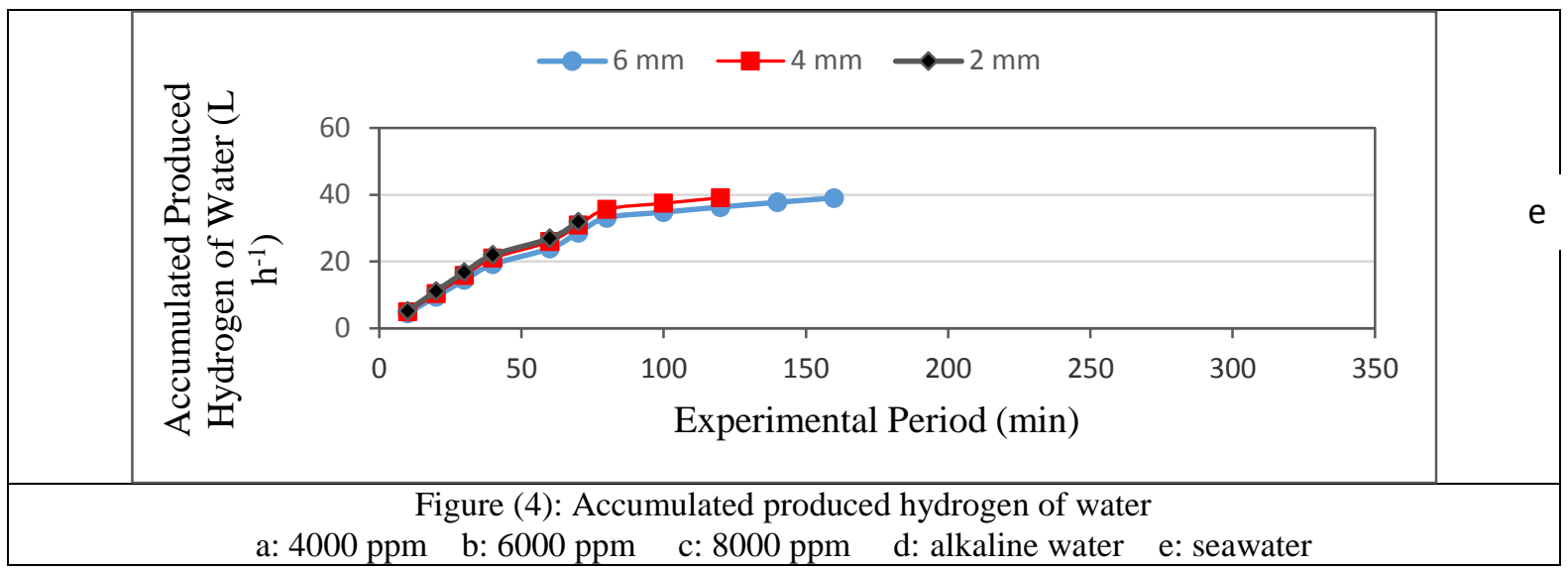

For water type of $8000 \mathrm{ppm}$, the accumulated produced hydrogen of water increased from 2.837 to 3.782 and 27.778 to $36.997 \mathrm{~kg} \mathrm{~h}^{-1}$, when the distance between electrodes decreased from 6 to $2 \mathrm{~mm}$, respectively after 10 and $140 \mathrm{~min}$ of operating time. The results also indicate that the operating time decreases with decrasing the distance betwwen electrodes. It could be seen that the operating time decreased from 220 to $140 \mathrm{~min}$, when the distance between electrodes decrease from 6 to $2 \mathrm{~min}$, respectively.

The regression between the accumulated produced hydrogen and operating time for different distance between electrodes $(6,4$ and $2 \mathrm{~mm}$ ) for $8000 \mathrm{ppm}$ water type is show the following equation:

$$
\begin{array}{cc}
\text { For } 6 \mathrm{~mm} & \mathrm{PE}=2.726 \mathrm{OT}+15.904 \\
& \mathrm{R}^{2}=0.98 \\
\text { For } 4 \mathrm{~mm} & \mathrm{PE}=0.883 \mathrm{OT}+13.189 \\
& \mathrm{R}^{2}=0.97 \\
\text { For } 2 \mathrm{~mm} & \mathrm{PE}=0.356 \mathrm{OT}+7.632 \\
& \mathrm{R}^{2}=0.95
\end{array}
$$

For water type of alkaline water $(10 \%$ wt $\mathrm{KOH})$, the results indicate that the accumulated produced hydrogen of water increased from 3.782 to 4.728 and 25.768 to $30.732 \mathrm{~kg} \mathrm{~h}^{-1}$, when the distance between electrodes decreased from 6 to $2 \mathrm{~mm}$, respectively after 10 and 70 min of operating time. The results also indicate that the operating time decreases with decrasing the distance betwwen electrodes. It could be seen that the operating time decreased from 180 to 70 min, when the distance between electrodes decrease from 6 to $2 \mathrm{~min}$, respectively.

The regression between the accumulated produced hydrogen and operating time for different distance between electrodes $(6,4$ and $2 \mathrm{~mm})$ for water add koh type is show the following equation:

For $6 \mathrm{~mm}$

$\mathrm{PE}=4.997 \mathrm{OT}+46.334 \quad \mathrm{R}^{2}=0.97$

For $4 \mathrm{~mm}$

$\mathrm{PE}=1.624 \mathrm{OT}+13.406 \quad \mathrm{R}^{2}=0.98$

For $2 \mathrm{~mm}$

$\mathrm{PE}=0.502 \mathrm{OT}+5.606 \quad \mathrm{R}^{2}=0.99$

For water type of seawater, the results indicate that the accumulated produced hydrogen of water increased from 4.492 to 5.201 and 28.604 to 31.914 $\mathrm{kg} \mathrm{h} \mathrm{h}^{-1}$, when the distance between electrodes decreased from 6 to $2 \mathrm{~mm}$, respectively after 10 and 70 min of operating time. The results also indicate that the operating time decreases with decrasing the distance betwwen electrodes. It could be seen that the operating time decreased from 180 to $70 \mathrm{~min}$, when the distance between electrodes decrease from 6 to 2 min, respectively.

The regression between the accumulated produced hydrogen and operating time for different distance between electrodes $(6,4$ and $2 \mathrm{~mm})$ for seawater is show the following equation:

$$
\begin{array}{cc}
\text { For } 6 \mathrm{~mm} & \mathrm{PE}=5.699 \mathrm{OT}+66.538 \\
& \mathrm{R}^{2}=0.96 \\
\text { For } 4 \mathrm{~mm} & \mathrm{PE}=2.134 \mathrm{OT}+12.911 \\
& \mathrm{R}^{2}=0.98 \\
\text { For } 2 \mathrm{~mm} & \mathrm{PE}=0.565 \mathrm{OT}+4.784 \\
& \mathrm{R}^{2}=0.98
\end{array}
$$

\subsection{Accumulated energy output:}

Figure (5) shows the accumulated energy output at different water types $(4000 \mathrm{ppm}, 6000 \mathrm{ppm}, 8000$ ppm, alkaline water $(10 \%$ wt $\mathrm{KOH})$ and sea water $)$ and different distance between electrodes (6, 4 and $2 \mathrm{~mm}$ ) during the experimental period. The results indicate that the accumulated energy output increases with decreasing distance between electrodes and increases with increasing operating time. It could be seen that the accumulated energy output increased from 0.007 to 0.015 and 0.111 to $0.177 \mathrm{~kW} \mathrm{~h}$, when the distance between electrodes decreased from 6 to $2 \mathrm{~mm}$, respectively, for water type of $4000 \mathrm{ppm}$ after 10 and $180 \mathrm{~min}$ of operating time. The results indicate that the operating time decreases with decrasing the distance betwwen electrodes. It could be seen that the operating time decreased from 340 to $180 \mathrm{~min}$, when the distance between electrodes decrease from 6 to $2 \mathrm{~min}$, respectively, for water type of $4000 \mathrm{ppm}$.

For water type of $6000 \mathrm{ppm}$, the accumulated energy output increased from 0.010 to 0.018 and 0.093 to $0.172 \mathrm{~kW} \mathrm{~h}$, when the distance between electrodes decreased from 6 to $2 \mathrm{~mm}$, respectively after 10 and $160 \mathrm{~min}$ of operating time. The results also indicate that the operating time decreases with decrasing the distance betwwen electrodes. It could be seen that the 
operating time decreased from 260 to $160 \mathrm{~min}$, when the distance between electrodes decrease from 6 to 2 min, respectively.

For water type of $8000 \mathrm{ppm}$, the accumulated energy output increased from 0.012 to 0.016 and 0.137 to $0.180 \mathrm{~kW} \mathrm{~h}$, when the distance between electrodes decreased from 6 to $2 \mathrm{~mm}$, respectively after 10 and
$160 \mathrm{~min}$ of operating time. The results also indicate that the operating time decreases with decrasing the distance betwwen electrodes. It could be seen that the operating time decreased from 220 to $140 \mathrm{~min}$, when the distance between electrodes decrease from 6 to 2 min, respectively.

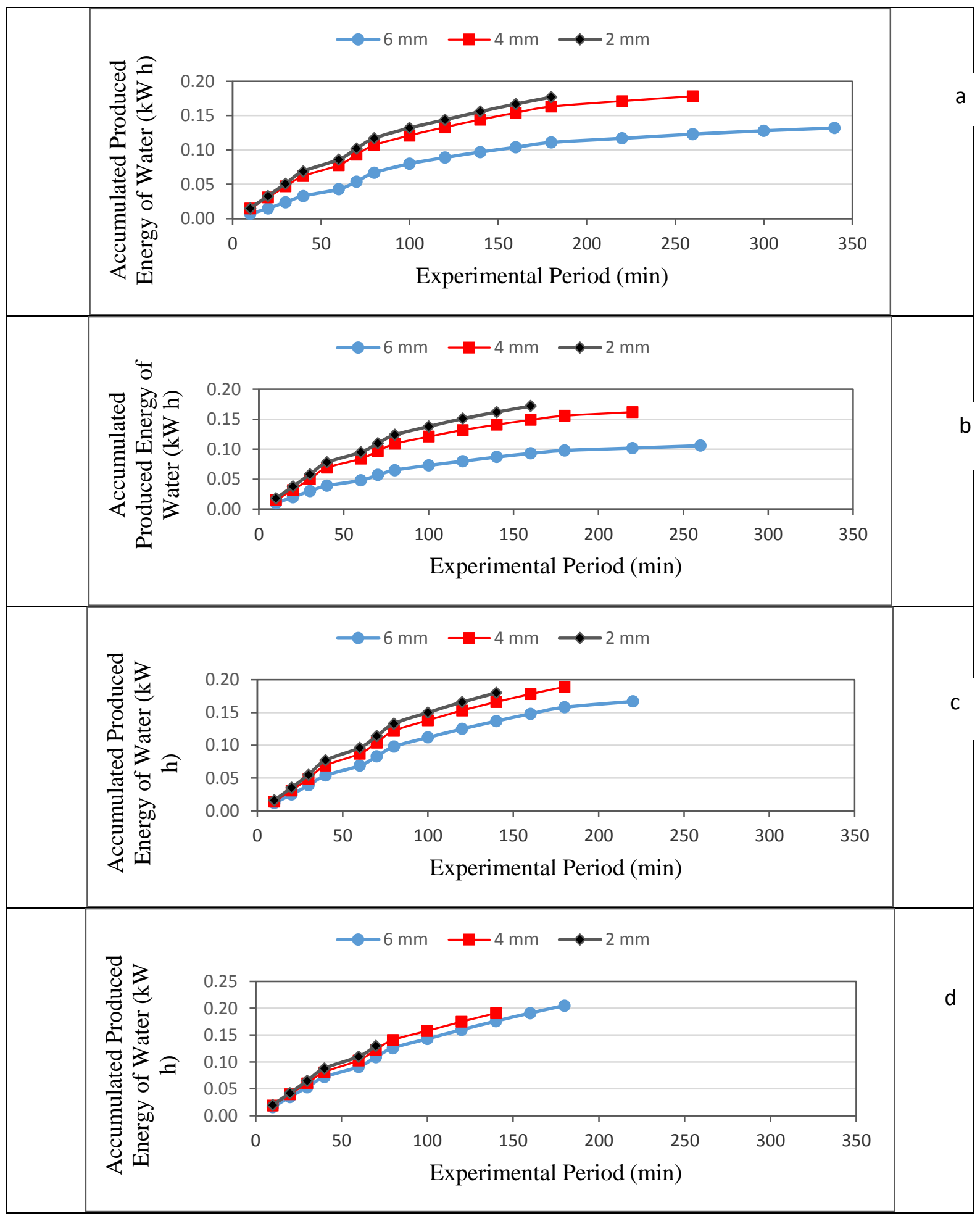




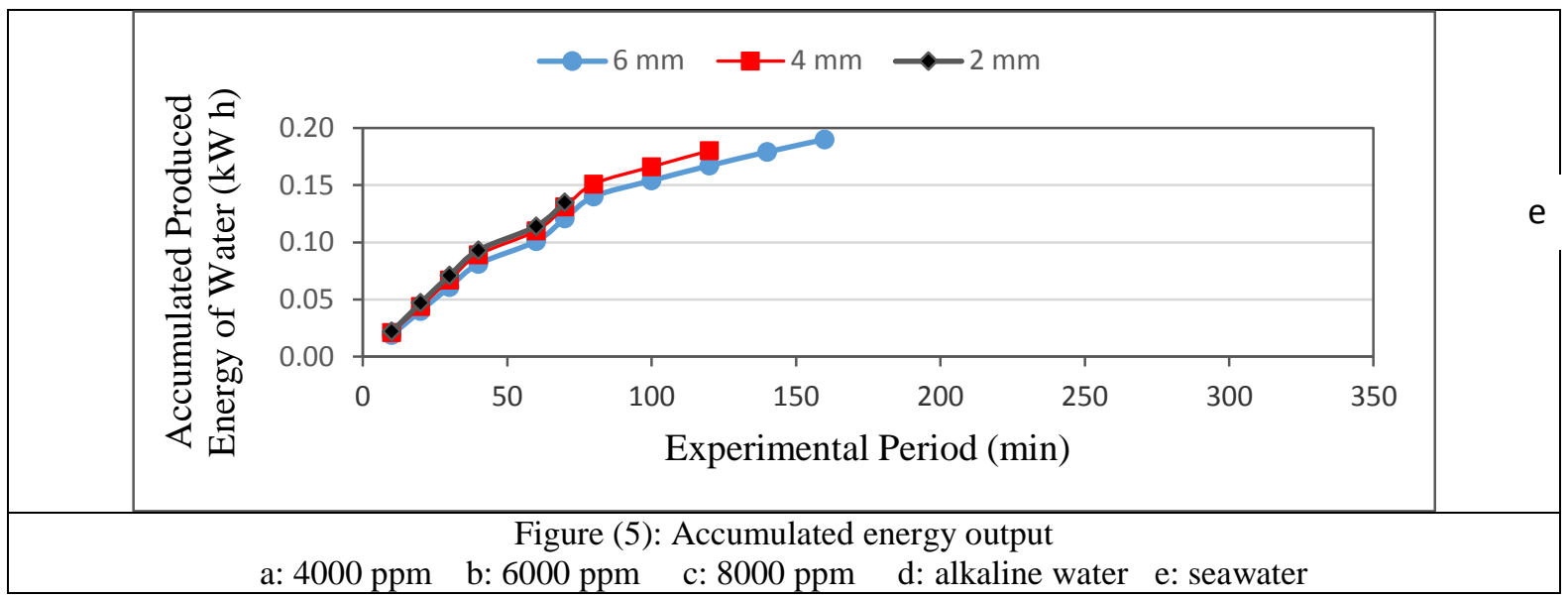

For water type of alkaline water $(10 \%$ wt $\mathrm{KOH})$, the accumulated energy output increased from 0.016 to 0.020 and 0.109 to $0.130 \mathrm{~kW} \mathrm{~h}$, when the distance between electrodes decreased from 6 to $2 \mathrm{~mm}$, respectively after 10 and $160 \mathrm{~min}$ of operating time. The results also indicate that the operating time decreases with decrasing the distance betwwen electrodes. It could be seen that the operating time decreased from 180 to $70 \mathrm{~min}$, when the distance between electrodes decrease from 6 to $2 \mathrm{~min}$, respectively.

For water type of seawater, the accumulated energy output increased from 0.019 to 0.022 and 0.121 to $0.135 \mathrm{~kW} \mathrm{~h}$, when the distance between electrodes decreased from 6 to $2 \mathrm{~mm}$, respectively after 10 and $160 \mathrm{~min}$ of operating time. The results also indicate that the operating time decreases with decrasing the distance betwwen electrodes. It could be seen that the operating time decreased from 160 to $70 \mathrm{~min}$, when the distance between electrodes decrease from 6 to 2 min, respectively.

\subsection{Hydrogen production unit efficiency:}

Figure (6) shows the hydrogen production unit efficiency at different water types (4000 ppm, 6000 ppm, 8000 ppm, alkaline water $(10 \%$ wt $\mathrm{KOH})$ and sea water) and different distance between electrodes $(6,4$ and $2 \mathrm{~mm})$ during the experimental period. The results indicate that the hydrogen production unit efficiency increases with decreasing distance between electrodes and also indicate that the hydrogen production unit efficiency increased gradually until it reached the peak and then decreased. It could be seen the hydrogen production unit efficiency increased from 25.36 to $64.10,27.78$ to 73.17 and 60.19 to 70.42 $\%$, when the distance between electrodes decreased from 6 to $2 \mathrm{~mm}$ after 10, 20 and $100 \mathrm{~min}$ of operating time, respectively, for water types of $4000 \mathrm{ppm}$.

The hydrogen production unit efficiency reached a maximum value was $60.19,68.38$ and $77.29 \%$ for 6 , 4 and $2 \mathrm{~mm}$ distance between electrodes, respectively, for water types of $4000 \mathrm{ppm}$. After the hydrogen production unit efficiency peak, a progressive decrease in hydrogen production unit efficiency is observed, to reach a final value of $29.63,47.62$ and $64.10 \%$ for 6,4 and $2 \mathrm{~mm}$ distance between electrodes, respectively.

For water type of $6000 \mathrm{ppm}$, the results indicate that the hydrogen production unit efficiency increased from 34.72 to $65.93,32.05$ to 68.03 and 29.96 to 56.91 $\%$, when the distance between electrodes decreased from 6 to $2 \mathrm{~mm}$ after 10, 20 and $100 \mathrm{~min}$ of operating time, respectively. Also, the hydrogen production unit efficiency reached a maximum value was $36.59,74.51$ and $80.32 \%$ for 6,4 and $2 \mathrm{~mm}$ distance between electrodes, respectively. After the hydrogen production unit efficiency peak, a progressive decrease in the hydrogen production unit efficiency is observed, to reach a final value of 22.60, 35.09 and $47.62 \%$ for 6,4 and $2 \mathrm{~mm}$ distance between electrodes, respectively. These results are in agreement with those obtained by Smolinka et al., (2011). 


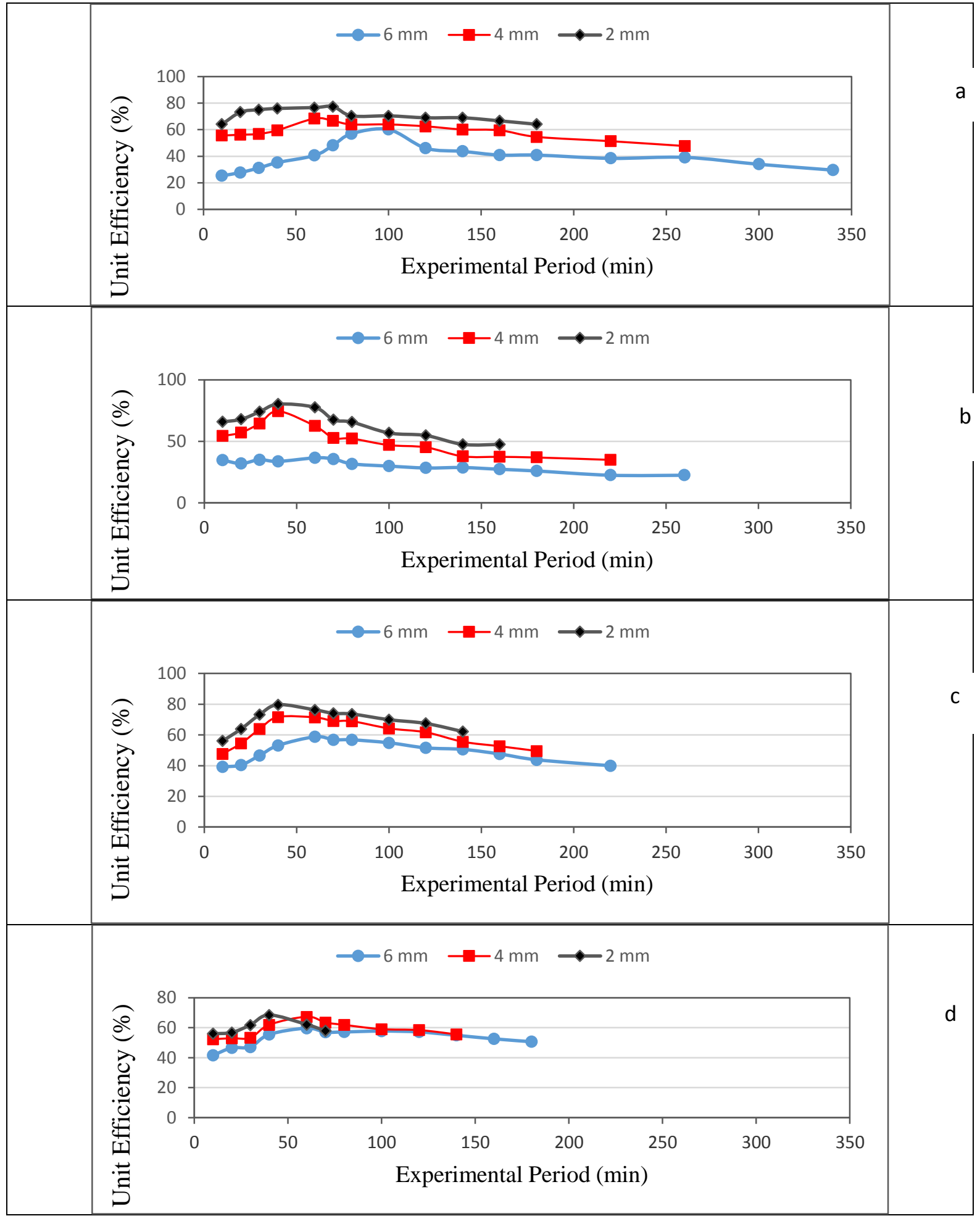




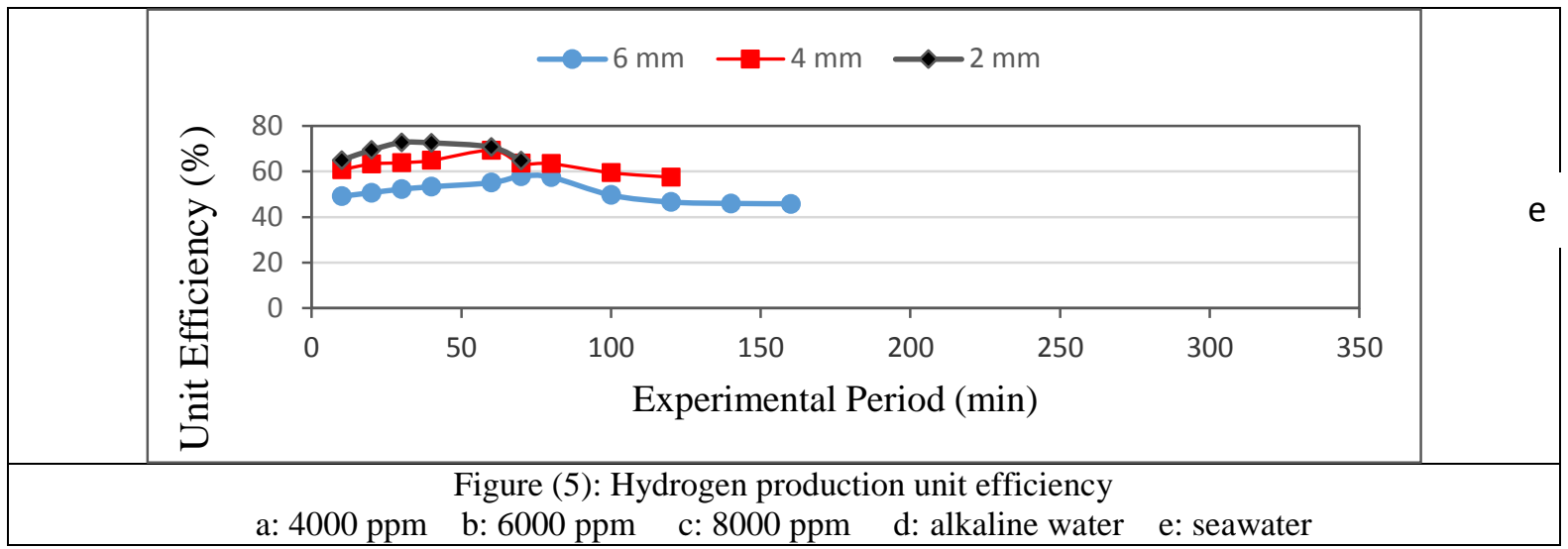

For water type of $8000 \mathrm{ppm}$, the results indicate that the hydrogen production unit efficiency increased from 39.22 to $56.14,40.50$ to 63.97 and 54.90 to 69.96 $\%$, when the distance between electrodes decreased from 6 to $2 \mathrm{~mm}$ after 10, 20 and $100 \mathrm{~min}$ of operating time, respectively. Also, the hydrogen production unit efficiency reached a maximum value was 58.82, 71.68 and $79.71 \%$ for 6,4 and $2 \mathrm{~mm}$ distance between electrodes, respectively. After the hydrogen production unit efficiency peak, a progressive decrease in the hydrogen production unit efficiency is observed, to reach a final value of 40.00, 49.55 and $62.22 \%$ for 6,4 and $2 \mathrm{~mm}$ distance between electrodes, respectively.

For water type of alkaline water $(10 \%$ wt $\mathrm{KOH})$, the results indicate that the hydrogen production unit efficiency increased from 41.67 to $56.02,46.57$ to 56.85 and 57.14 to $57.97 \%$, when the distance between electrodes decreased from 6 to $2 \mathrm{~mm}$ after 10 , 20 and $70 \mathrm{~min}$ of operating time, respectively. Also, the hydrogen production unit efficiency reached a maximum value was 59.75, 67.28 and $68.45 \%$ for 6 , 4 and $2 \mathrm{~mm}$ distance between electrodes, respectively. After the hydrogen production unit efficiency peak, a progressive decrease in the hydrogen production unit efficiency is observed, to reach a final value of 50.72 , 55.56 and $57.97 \%$ for 6,4 and $2 \mathrm{~mm}$ distance between electrodes, respectively.

For water type of seawater, the results indicate that the hydrogen production unit efficiency increased from 49.10 to $64.90,50.72$ to 69.44 and 57.97 to $64.81 \%$, when the distance between electrodes decreased from 6 to $2 \mathrm{~mm}$ after 10, 20 and $70 \mathrm{~min}$ of operating time, respectively. Also, the hydrogen production unit efficiency reached a maximum value was 57.97, 69.31 and $72.73 \%$ for 6,4 and $2 \mathrm{~mm}$ distance between electrodes, respectively. After the hydrogen production unit efficiency peak, a progressive decrease in the hydrogen production unit efficiency is observed, to reach a final value of 45.83 , 57.61 and $64.81 \%$ for 6,4 and $2 \mathrm{~mm}$ distance between electrodes, respectively.

\subsection{Costs:}

Table (1) shows the total costs of hydrogen production unit at different water types (4000 ppm, 6000 ppm, 8000 ppm, alkaline water (10\% wt KOH) and sea water) and different distance between electrodes $(6,4$ and $2 \mathrm{~mm})$ during the experimental period. The total costs of hydrogen production unit were $1.55,1.54$ and 1.53 L.E $\mathrm{kg}^{-1}$ of hydrogen production at 6,4 and $2 \mathrm{~mm}$ distance between electrodes, respectively, for water type of $4000 \mathrm{ppm}$. For water type of $6000 \mathrm{ppm}$, the total costs of hydrogen production unit were $1.56,1.55$ and 1.55 L.E $\mathrm{kg}^{-1}$ of hydrogen production at 6,4 and $2 \mathrm{~mm}$ distance between electrodes, respectively. For water type of $8000 \mathrm{ppm}$, the total costs of hydrogen production unit were $1.58,1.56$ and $1.55 \mathrm{~L} . \mathrm{E} \mathrm{kg}^{-1}$ of hydrogen production at 6,4 and $2 \mathrm{~mm}$ distance between electrodes, respectively. For water type of alkaline water $(10 \%$ wt $\mathrm{KOH})$, the total costs of hydrogen production unit were $1.61,1.58$ and 1.58 L.E $\mathrm{kg}^{-1}$ of hydrogen production at 6,4 and $2 \mathrm{~mm}$ distance between electrodes, respectively. For water type of seawater, the total costs of hydrogen production unit were $1.60,1.58$ and $1.58 \mathrm{~L} . \mathrm{E} \mathrm{kg}^{-1}$ of hydrogen production at 6,4 and $2 \mathrm{~mm}$ distance between electrodes, respectively.

Table 1. The total costs of hydrogen production unit.

\begin{tabular}{lccc}
\hline & \multicolumn{3}{c}{ Distance between cells, $\mathbf{~ m m}$} \\
\cline { 2 - 4 } Water type & $\mathbf{6}$ & $\mathbf{4}$ & $\mathbf{2}$ \\
\cline { 2 - 4 } & & $\mathbf{C o s t}, \mathbf{L . E} \mathbf{~ k g}^{-\mathbf{1}}$ & 1.53 \\
$\mathbf{4 0 0 0} \mathbf{~ p p m}$ & 1.55 & 1.54 & 1.55 \\
$\mathbf{6 0 0 0} \mathbf{~ p p m}$ & 1.56 & 1.55 & 1.55 \\
$\mathbf{8 0 0 0} \mathbf{~ p p m}$ & 1.58 & 1.56 & 1.58 \\
alkaline water & 1.61 & 1.58 & 1.58 \\
Seawater & 1.60 & 1.58 & \\
\hline
\end{tabular}




\section{Conclusion}

The experiment was carried out to study the possibility of producing hydrogen gas from water by electrolysis as renewable source of energy. The treatments under study are: different water type $(4000$ ppm, 6000 ppm, 8000 ppm, alkaline water (10\% wt $\mathrm{KOH})$ and seawater) and different distance between electrodes (6, 4 and $4 \mathrm{~mm})$. The obtained results can be summarized as follows:

- The accumulated energy requirements increases with decreasing distance between electrodes and increases with increasing operating time.

- The highest values of accumulated energy requirements were $0.334,0.342,0.340,0.389$ and $0.368 \mathrm{~kW}$ h for $4000 \mathrm{ppm}, 6000 \mathrm{ppm}, 8000 \mathrm{ppm}$, water alkaline water $(10 \%$ wt $\mathrm{KOH})$ and seawater of types of water, respectively at $6 \mathrm{~mm}$ distance between electrodes.

- The accumulated produced hydrogen of water increases with decreasing distance between electrodes and increases with increasing operating time. The accumulated produced hydrogen of water ranged from 1.655 to $36.997 \mathrm{~L} \mathrm{~h}^{-1}$ for all treatments.

- The accumulated energy output increases with decreasing distance between electrodes and increases with increasing operating time. The accumulated produced energy of water ranged from 0.007 to $0.180 \mathrm{~kW} \mathrm{~h}$ for all treatments.

- The hydrogen production unit efficiency increases with decreasing distance between electrodes and also indicate that the hydrogen production unit efficiency increased gradually until it reached the peak and then decreased. The hydrogen production unit efficiency ranged from 25.36 to $80.32 \%$ for all treatments.

- The total costs of hydrogen production unit ranged from 0.040 to $0.069 \mathrm{LE} \mathrm{kg}^{-1}$ of hydrogen production.

\section{References}

IEA (International Energy Agency) (2005). Key World Energy Statistics,

Saur, G. (2008). Wind-to-hydrogen Project: Electrolyzer Capital Cost Study U.S. National Renewable Energy Laboratory, Golden, U.S.A.

Balat, M. (2008). Potential importance of hydrogen as a future solution to environmental and transportation problems. International Journal of Hydrogen Energy, 33 (2008), 4013-4029.

Muradov, N.Z. and T.N. Veziroglu (2008). Green path from fossil-based to hydrogen economy: an overview of carbon-neutral technologies. International Journal of Hydrogen Energy, 33, 6804-6839.

Smolinka, T., M. Günther and J. Garche (2011). Stand und Entwicklungspotenzial der Wasserelektrolyse zur Herstellung von Wasserstoff aus regenerativen Energien.
Nationale Organisation Wasserstoff- und Brennstoffzellentechnologie (NOW $\mathrm{GmbH})$, Berlin.

Spath, P.L. and M.K. Mann (2001). Life Cycle Assessment of Hydrogen Production via Natural Gas Steam Reforming U.S. National Renewable Energy Laboratory, Golden, U.S.A.

USDOE (2009). Hydrogen Production - Overview of Technology Options. Freedom Car and Fuel Partnership Project EERE, DOE.

Rajeshwar, K., R. Mcconnell AND S. Licht (2008). Solar Hydrogen Generation. toward a Renewable Energy Future Springer, New York.

Romagnoli, F., D. Blumberga and I. Pilicka (2011). Life cycle assessment of biohydrogen production in photosynthetic processes. International Journal of Hydrogen Energy, 36, 7866-7871.

International Pe (2010). Hydrogen production from renewable energy by electrolysis Centre for Research into Energy for Sustainable Transport (CREST), Perth, Australia.

Pehnt M. (2001). Ganzheitliche Bilanzierung von Brennstoffzellen in der Energie- und Verkehrstechnik. Doktor Disseration Universität Stuttgart.

Dufour, J., D.P. Serrano, J.L. Galvez, J. Moreno and A. Gonzalez (2011). Hydrogen production from fossil fuels: life cycle assessment of technologies with low greenhouse gas emissions. Energy \& Fuels, 25, 2194-2202.

Padro, C.E.G. and V. Putsche (1999). Survey of the Economics of Hydrogen Technologies, National Renewable Energy Laboratory (NREL), Golden (Colorado, USA).

Häussinger, P., R. Lohmüller and A.M. Watson (2007). Hydrogen. Ullmann's Encyclopedia of Industrial Chemistry Wiley-VCH Verlag $\mathrm{GmbH}$ and $\mathrm{Co}$. KGaA.

Holladay, J.D., J. Hu, D.L. King and Y. Wang (2009). An overview of hydrogen production technologies. Catalysis Today, 139, 244-260.

Momirlan, M., and T.N. Veziroglu (2002). Current status of hydrogen energy Renewable \& Sustainable Energy Reviews, 6, 141-179.

Ursua, A., L.M. Gandia and P. Sanchis (2012). Hydrogen production from water electrolysis: current status and future trends. Proceedings of the IEEE, 100, 410-426.

Stojic, D.L., M.P. Marceta, S.P. Sovilj and S.S. Miljanic (2003). Hydrogen generation from water electrolysis - possibilities of energy saving. Journal of Power Sources, 118, 315-319.

Wenske, M. Wasserstoff H. and X.V. Elektrolyse (2008). energie-symposium: Nutzung regenerativer Energiequellen und Wasserstofftechnik, Fachhochschule Stralsund, Fachhochschule Stralsund, Stralsund.

Osterloh, F.E. (2008). Inorganic materials as catalysts for photochemical splitting of water. Chem Mater, 2008(20), 35-54. 


\section{أمكانية انتاج الهيدرجين من المياه بالتحليل الكهريى كمصدر للطاقة المتجددة

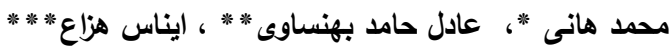 \\ *طالب دراسات عليا - كلية الزراعة - جامعة دمنهور

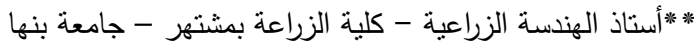 \\ (مدرس الهندسة الزراعية - كلية الزراعة - جامعة دمنهور}

يهدف هذا البحث الى دراسة اماكنية انتاج الهيدروجين من المياه بالتحليل الكهربى كمدر للطاقة المتجددة. ولتحقيق ذلك نم تطوير وحدة بسيطة لتحليل المياه وتقيمها من خلال استخدام خمس انواع من المياه (ذات ملوحة 4000 جزء فى المليون، 6000 جزء فى المليون، 8000 جزء فى المليون ومياء قلوية ومياه البحر) وثلاثة مسافات بين الأقطاب (6، 4، 2 مح) وتاثيرها على كلا من الطاقة المستهلكة والهيدروجين الناتج والطاقة الناتجة والكفاؤة وتكاليف النتغيل. وكانت اهئ اهم النتائج: زادت الطاقة المطلوبة لانتاج الهيدروجين بتقليل المسافة بين الاقطاب وزيادة وقت التشغيل. زادت انتاجية النيتروجين بتقليل المسافة بين الاقطاب وزيادة وقت التشغيل حيث تراوحت انتاجية النيتروجين من 1.977 الى 1.997 لتر ساعة-1 لكل المعاملات. زادت الطاقة الناتجة بتقليل المسافة بين الاقطاب وزيادة وقت النتغيل حيث تراوحت الطاقة الناتجة من 0.007 الى 0.180 كيلو وات ساعة لكل المعاملات. تراوحت كفاءة وحدة انتاج الهيدروجين من 25.36 الى 80.32 \% لكل المعاملات. بينما تراوحت التكاليف الكلية لتشغيل الوحدة ما بين 0.040 الى 0.069 جنيه لكل كجم هيدروجين ناتج. 